\title{
Rotifers in Lake Orta: a potential ecological and evolutionary model system
}

\author{
Stefan SOMMER, ${ }^{1}$ Sarma NANDINI, ${ }^{2}$ S.S.S. SARMA,${ }^{2}$ Arpat OZGUL,,${ }^{1}$ Diego FONTANETO ${ }^{3 *}$ \\ ${ }^{1}$ Department of Evolutionary Biology and Environmental Studies, Population Ecology Research Group, University of Zurich, CH-8057 \\ Zürich, Switzerland; ${ }^{2}$ Division of Research and Postgraduate Studies, Laboratory of Aquatic Zoology, National Autonomous University \\ of Mexico, Campus Iztacala Av. de Los Barrios No.1, C.P. 54090, Los Reyes, Tlalnepantla, State of Mexico, Mexico; ${ }^{3}$ National Research \\ Council, Institute of Ecosystem Study, Largo Tonolli 50, I-28922 Verbania Pallanza, Italy \\ *Corresponding author: d.fontaneto@ise.cnr.it
}

\begin{abstract}
Lake Orta experienced for a few decades a unique history of chronic pollution, with extreme changes in pH and copper concentration. Currently, the lake has recovered to its almost pristine oligotrophic conditions, but its sediments still preserve the record of all the changes that happened since the establishment of the first polluting factories in the 1920s, through to the liming activities in 19891990, and to the recovery phase that is still going on. Here we review the current knowledge for Lake Orta regarding rotifers, a diverse component of the zooplankton of the lake, through studies on living organisms and on their resting stages accumulated in the sediments. We also report a brief review of what is known in general on the effects of changes in $\mathrm{pH}$ and copper concentration on rotifers at the population, species and community level, providing expectations for such effects on the rotifers of Lake Orta. Then, we conclude our review with a perspective on the potential use of rotifers hatched from the resting stages in the sediment of Lake Orta with the description of experiments that can be performed in the future in the framework of resurrection ecology, in order to understand the mechanisms of past and future changes in the environment.
\end{abstract}

Key words: Resting egg; resurrection ecology; Rotifera, zooplankton.

Received: June 2015. Accepted: October 2015.

\section{INTRODUCTION}

Resting stages, subfossil remains, and other traces of organisms living in the water column accumulate in the sediment at the bottom of water bodies and may represent an archive of past changes, to be used to predict the future (Orsini et al., 2013; Taranu et al., 2015). Such biological archives in the sediments can be used when the history of past changes in the water body is well documented, and Lake Orta in Northern Italy represents one such model environment. Lake Orta has been an emblematic case of industrial pollution by heavy metals and acidifying compounds, and it became the largest acidified deep lake in the world (Calderoni and Tartari, 2001). Located in the subalpine region, Lake Orta is a deep (max depth: $143 \mathrm{~m}$ ), oligotrophic, monomictic lake (Bonacina, 2001). It became chronically polluted after a rayon factory was established at the southern end of the lake in 1926, discharging huge amounts of copper and ammonium sulfate into the water (Calderoni et al., 1990; Bonacina and Baudo, 2001). The biochemical oxidation of $\mathrm{N}-\mathrm{NH}_{4}$ caused nitrate $\left(\mathrm{N}-\mathrm{NO}_{3}\right)$ accumulation and a strong decrease in the $\mathrm{pH}$ of the lake, which was poorly buffered due to the acidic geology of the catchment. Immediately after the discharge started, most living organisms disappeared from the lake (Monti, 1930; Bonacina, 2001).

Since the onset of pollution, copper concentration in the water column kept increasing. The low $\mathrm{pH}$ values of the water column helped in keeping high levels of copper and other toxic heavy metals (Calderoni and Tartari, 2001). During this second phase, a species-poor community characterised the plankton, mainly composed of $C y$ clops abyssorum (copepod), Hexarthra fennica (rotifer), and Coccomyxa minor (green alga), whereas fish and benthic animals were still almost absent (Vollenweider, 1963; Bonacina, 1970).

From 1958 on, copper was recovered from the factory effluent prior to discharge into the lake. Ammonium discharge stopped in 1980 when a law regulating discharge of industrial wastes into freshwater environments was established in Italy. Liming activities were performed in May 1989-June 1990 and resulted in a rapid improvement of the chemical conditions of the lake, the recovery of the pristine environmental state, coupled with the re-colonisation of several organisms of the zooplankton (Bonacina et al., 1994; Bonacina and Pasteris, 2001). Thus, the lake experienced drastic and rapid changes in $\mathrm{pH}$ and copper, strongly affecting the zooplankton in the water column. The $\mathrm{pH}$ of the lake went from neutral in the pre-pollution phase before 1926, to very acidic conditions (down to 3.9) from the 1960s to the 1980s, and then recovered after the liming activities to become neutral again after 2000. Copper in the water column went from absent before the pol- 
lution phase, steeped to extremely high values (up to 108 $\mu \mathrm{g} / \mathrm{L}$ ) at the end of the $1950 \mathrm{~s}$, and gradually decreased until it disappeared again after 2000 (Calderoni and Tartari, 2001; Rogora et al., 2016).

The zooplankton of the lake represents an interesting model system that could be exploited to understand the relative role of adaptation, dispersal, and turnover in the eco-evolutionary dynamics that happened during the rapid changes in the environmental conditions. Animals living in the lake could have adapted rapidly to the changing conditions of $\mathrm{pH}$ and heavy metal concentrations; alternatively, rare genotypes or animals arriving from outside the lake through resting stages could have been already more adapted to the new conditions than the common and resident populations and species. These scenarios can be analysed nowadays thanks to the resting stages that accumulate in the sediments through the different phases of pollution in the lake.

The effects of changes in $\mathrm{pH}$ and copper concentration in Lake Orta have been extensively studied in the zooplankton, focusing mostly on cladocerans (Manca and Comoli, 1995; Cattaneo et al., 1998; Ponti et al., 2010). The result of these studies is that an almost complete change in the cladoceran community happened in the lake several times in relation to the changes in environmental conditions during pollution and even during the recovery phases (Bonacina and Pasteris, 2001). Yet, resting stages of cladocerans, called ephippia, even if found in the sediment, cannot be always resurrected for lab tests and genetic analyses (Piscia et al., 2012). On the other hand, resting eggs of some rotifer species found in the lake sediment are often viable: resting eggs of Brachionus calyciflorus have been resurrected and DNA was successfully extracted and amplified from them for a period spanning from the pre-, during, and post-pollution phases (Piscia et al., 2012). This possibility opens the future for studies in the ecological and evolutionary aspects of the effect of pollution in the framework of resurrection ecology (Decaestecker et al., 2007; Orsini et al., 2013). Also, more species of rotifers are usually present in the plankton than cladocerans, changes in rotifer composition were more drastic than those of cladocerans in Lake Orta (Bonacina and Pasteris, 2001), and more diversity was found in the resting eggs in the lake sediments than for cladoceran ephippia (Piscia et al., 2012). Thus, several rotifer species could be used for resurrection ecology.

Here we review (1) what is known in Lake Orta regarding rotifers during all the phases of the lake, and (2) what is known in general on the effects of changes in $\mathrm{pH}$ and copper concentration on rotifers. Finally, (3) we provide a perspective on potential experiments that could be performed using this information to set up experimental studies in a unifying framework to understand the effects of a rapidly changing environment on the biota.

\section{Review of rotifers from Lake Orta}

Rotifers were known to be diverse and abundant in the pre-pollution phase, but no species list is available from that period (Monti, 1930). During the pollution, the lowest diversity was reached at the onset of the problems, with no rotifers living in the lake (Monti, 1930). During the pollution peaks, only Brachionus calyciflorus and Hexarthra fennica seemed to survive (Bonacina and Pasteris, 2001).

Then, from the $1980 \mathrm{~s}$, when ammonium levels decreased, B. calyciflorus and $H$. fennica continued their occurrence, together with at least Asplanchna brightwellii, B. urceolaris, Keratella cochlearis, K. quadrata, Lecane luna, and Anuraeopsis fissa (Bonacina and Pasteris, 2001).

In the post-pollution period, after the liming activities in 1989-1990 to 1997, at least 45 species of rotifers were found in the lake (Bonacina and Pasteris, 2001), a comparable number to what is known from the plankton of nearby lakes, unaffected by the levels of pollution of Lake Orta (e.g., Lake Maggiore: 40, Obertegger and Manca, 2011; Boggero et al., 2014), and within the range of species diversity that is expected for the plankton of an oligotrophic lake at temperate latitudes (Muirhead et al., 2006). Planktonic rotifers present in the recovery phase represented all functional guilds, including filter-feeders, browsers, scrapers, piercers, and even predators such as Asplanchna brightwellii and A. priodonta (Bonacina and Pasteris, 2001).

Regarding population dynamics, Hexarthra fennica gave rise to blooms during the pollution phases (Baldi, 1949; Bonacina, 1970), but was then represented by very few individuals after the liming (Bonacina and Pasteris, 2001); in the post-pollution period, the overall densities have been rather low for most rotifers, but some species occasionally reached very high densities: for example Keratella quadrata peaked with 180,000 individuals $/ \mathrm{m}^{3}$ in April 1994 (Bonacina and Pasteris, 2001).

A study on rotifer resting eggs from sediment cores in the lake revealed the presence of at least 12 morphological types (Piscia et al., 2012). Among these, six appeared only during the recovery, whereas one morphotype, identified by DNA taxonomy as Brachionus calyciflorus, was present throughout all the sediment layers back in time through more than a century. Surprisingly, the DNA sequences of the resting eggs of $B$. calyciflorus from the pre-, during and post-pollution phases represented the same mtDNA haplotype through time. This species is highly variable in the analysed mtDNA fragment (Papakostas et al., 2016); thus, the fact that only one haplotype was found in the lake suggests that this species was able to quickly adapt locally through priority effects and monopolisation (De Meester et al., 2002), and no foreign mtDNA haplotypes managed to colonise the lake during its fluctuating conditions. 


\section{Effects of $\mathrm{pH}$ and copper on rotifers at the community level}

Zooplankton in general and rotifers in particular are negatively affected by acidification stresses (Brett, 1989; Waervagen and Nilssen, 2003; Gray and Arnott, 2009). Lakes at different $\mathrm{pH}$ naturally host different communities, with more acidic lakes generally hosting fewer species (Bielanska-Granier, 2001; Weisse et al., 2013). Yet, rotifer communities are known to be present in water bodies with different $\mathrm{pH}$. Even lakes with $\mathrm{pH}<3$ can host rotifer species, regardless of whether such low acidity is natural, due to volcanism, or due to mining activities (Deneke, 2000). On the other hand, no rotifer community is usually found in the plankton of lakes at $\mathrm{pH}>10$, if not for the occasional occurrence of one species of Brachionus (Pejler, 1974). Rotifer communities at these extreme values, with $\mathrm{pH}<3$ or $>10$, are very poor and usually host only one or two species (Weithoff, 2005; Moser and Weisse, 2011; Amaral-Zettler, 2012).

The interrelations between rotifer communities and $\mathrm{pH}$, temperature, and other physical and chemical variables can be complex and difficult to disentangle (Kaya et al., 2010), and thus a clear picture of the pure effect of $\mathrm{pH}$ may be misinterpreted due to other study-specific confounding factors. In order to avoid this problem, a comprehensive review of preferences of hundreds of species of rotifers to $\mathrm{pH}$ was performed in Sweden and highlighted the fact that no particular correlation was found between $\mathrm{pH}$ and any other environmental factor (Bērzinš and Pejler, 1987). The same review suggested that rotifer species living in oligotrophic water bodies generally had their $\mathrm{pH}$ optima at or below 7 , whereas the species living in eutrophic water bodies occurred at or above this level. Rotifers found in acidic waters are often non-planktonic or semi-planktonic (Bērzinš and Pejler, 1987). Overall, rotifers may occur in water bodies at $\mathrm{pH}$ between 3 and 10 , but different species respond differently to changes in $\mathrm{pH}$. All the species that have been analysed spanned at least two and up to five units of $\mathrm{pH}$ (Bērzinš and Pejler, 1987). Yet, all this information was based on species identification performed on morphology only, whereas it is only now known that rotifer taxonomy may be biased by high levels of morphological stasis producing complexes of cryptic species (Fontaneto, 2014). Different cryptic species within a complex may even respond in opposite ways to the same environmental driver (Obertegger et al., 2012), enhancing the effect of changes in $\mathrm{pH}$ in water bodies.

Overall, a summary of the studies here reported on the effects of changes in community composition in rotifers in relationship to the changes in $\mathrm{pH}$ such as those that occurred in Lake Orta can be that: i) changes in community composition are indeed expected; ii) the effects of such changes are likely to be community-specific, context de- pendent, and different between plankton and benthos; iii) extreme levels of $\mathrm{pH}$ will impoverish the communities, but these communities could recover rather quickly after pristine conditions are restored. Species-specific responses to changes in $\mathrm{pH}$, accounting for the overall response of the communities, will be detailed in the following section, focusing on the species that have been tested in the laboratory.

Regarding changes in copper concentration in the water column, not much is known on such effects on rotifer communities. Copper is an essential trace element, yet toxic to zooplankton in high concentrations (McIntosh and Kevern, 1974; Beers et al., 1977). The concentration and complexation of copper and other heavy metals in water is highly dependent on other factors, e.g. $\mathrm{pH}$ and hardness, and the pure effect of heavy metals on rotifers in the field is unclear (Buikema et al., 1974; Borgmann and Ralph, 1984; Arnold et al., 2010). One palaeolimnological study tried to address the issue of rotifer diversity in relation to copper analysing resting eggs in different sediment layers corresponding to different levels of copper concentrations in Lake Orta, and rotifer diversity indeed appeared to be negatively related to copper concentration (Piscia et al., 2012). Knowledge on the effects of copper and other heavy metals on rotifer communities in the field is still vague, whereas several studies used laboratory experiments with ecotoxicological approaches at the species level (Snell and Janssen, 1995): they are described in detail in the following section, in order to understand the potential effects of copper on rotifers in Lake Orta.

\section{Effects of $\mathrm{pH}$ and copper on rotifers at the population level}

Rotifers are sensitive bioindicators of aquatic toxicity and hence several species are frequently used in ecotoxicological bioassays. The use of rotifers in ecotoxicology may have a wider impact than that of the study of Lake Orta. Anthropogenic effects are often adverse on natural systems: two of the main reasons for the deterioration of water bodies are eutrophication and acidification (Gulati and van Donk, 2002). The latter has been a very relevant problem until recently in Europe (Guerreiro et al., 2014) with high concentrations of nitrogen and sulphur in the atmosphere resulting in acid rain having a $\mathrm{pH}$ of 4.7 instead of the normal 5.2. Thus, what is known on rotifers and on Lake Orta may help predicting the effect of restoration activities in other water bodies.

The $\mathrm{pH}$ in aquatic ecosystems plays an important role in various ways influencing at the same time animal diversity and the availability of heavy metals (Lampert and Sommer, 1997). Copper is an essential element, which is toxic at concentrations as low as $1 \mu \mathrm{g} \mathrm{L^{-1 }}$ (Roesijadi, 1992). Its availability and toxicity increases as the $\mathrm{pH}$ de- 
creases (Hyne et al., 2005). In the case of green algae, however, Franklin et al. (2000) have shown that the toxicity of copper is greater at a $\mathrm{pH}$ of 6.5 than at 5.7. Many other abiotic factors also influence the toxicity of copper. For example, temperature accelerates the toxicity of copper (Boeckman et al., 2006). With projected increase in global warming (Root et al., 2003), the effect of heavy metals including copper to organisms can be still more disastrous than it is generally thought.

Commonly used species of rotifers for ecotoxicological bioassays include various members of the family Brachionidae, such as Brachionus calyciflorus and Plationus patulus in freshwater systems and some taxa of the Brachionus plicatilis species complex in marine waters (Snell and Janssen, 1995; Gama-Flores et al., 1999; Luna-Andrade et al., 2002; Snell and Joaquim-Justo, 2007; Sarma et al., 2008). As compared to other zooplankton, several taxa of rotifers can tolerate acid conditions rather well (Bērzinš and Pejler, 1989a, 1989b, 1989c); Brachionus is, however, a typically alkaline genus and is most diverse at a $\mathrm{pH}$ ranging from 7-9. Sub-lethal concentrations of copper below $5 \mu \mathrm{g} \mathrm{L}{ }^{-1}$ result in population growth rates very similar to the controls; at concentrations above this threshold the adverse effects of copper are observed. Saline and marine species are more resistant to copper; studies show that B. plicatilis can tolerate concentrations up to $125 \mu \mathrm{g} \mathrm{L}^{-1}$, but under conditions of high food availability $\left(0.2 \times 10^{6}\right.$ cells $\mathrm{mL}^{-1}$ ) of Tetraselmis suecica (Luna-Andrade et al., 2002). Brachionus rotundiformis can tolerate copper concentrations of $31.25 \mu \mathrm{g} \mathrm{L}^{-1}$ and has a higher growth rate at this concentration as compared to controls under appropriate salinity conditions $\left(5 \mathrm{~g} \mathrm{~L}^{-1}\right)$ (Gama-Flores et al., 1999). The population growth rates range from +0.31 to -0.12 depending on the test conditions and sublethal concentrations of copper in this species. Brachionid rotifers typical of alkaline waters are more tolerant to high concentrations of copper: in Lake Nakuru, Kallqvist and Meadows (1978) reported that Brachionus sp. could tolerate up to $500 \mu \mathrm{g}$ $\mathrm{L}^{-1}$ of copper.

Littoral taxa of rotifers have also been used to assess their sensitivity to copper. Sarma et al. (2010), working with Lecane quadridentata, observed that this species is more sensitive than P. patulus: at concentrations above 1.25 $\mu \mathrm{g} \mathrm{L}^{-1}$ of copper they were unable to grow. This is more than an order of magnitude lower than the tolerance levels of planktonic rotifers. The results on littoral taxa are similar to those of littoral species other than rotifers such as the hydrozoan Hydra viridissima (Markich and Camilleri, 1997), which cannot tolerate concentrations above $1.8 \mu \mathrm{g} \mathrm{L}^{-1}$.

In addition to short-term toxicity tests and population demography studies, behavioural observations and biochemical assays are also sensitive indicators of the response of planktonic rotifer to copper. Janssen et al. (1994) observed slower swimming speeds in Brachionus calyciflorus at concentrations above $0.22 \mathrm{mg} \mathrm{L}^{-1}$ but increased exposure time to the toxicant resulted in significantly lower swimming speeds. This clearly indicates that even if short-term $\mathrm{LC}_{50}$ studies are close to the tolerance levels, long term exposure, as is common in aquatic systems, would have a deleterious effect on the populations. Studies also show that copper induces lipid peroxidation activity (Enesco et al., 1989) and the production of stress proteins such as SP58 (Cochran et al., 1991), both of which reduce the life span of rotifers.

\section{Resurrection ecology of rotifers in Lake Orta: planning an experiment}

Investigating how natural populations respond to environmental change is notoriously difficult due to the time frame required for conducting such studies. An elegant method that overcomes these constraints is the resurrection of dormant propagules and the subsequent study of resurrected individuals - and their offspring - under controlled conditions in the laboratory (resurrection ecology sensu Kerfoot et al., 1999). Such an experimental approach, in combination with genetic analyses (see Orsini et al., 2013), provides a window into the past for studying eco-evolutionary dynamics retrospectively and in a much shorter time. In this section we describe how rotifer resting eggs can be collected from lake sediments, how they are induced to hatch, and how hatchlings can be cultured in order to establish rotifer populations to be used for experimental work. Finally, we provide an outlook on a recently started research programme aimed at investigating life-history responses to industrial pollution in brachionid rotifers resurrected from Lake Orta sediments.

Sediment samples from the lake bed can be collected by means of a gravity corer, in agreement with previous studies in Lake Orta (Cattaneo et al., 1998; Piscia et al., 2012). Sediment cores should be collected in different parts of the lake, covering the Southern, Central and Northern part of the water body. Cores should be brought to the laboratory, where they are cut in half along the longitudinal axis with one half of the cores being used for stratigraphy based on radioisotope analyses (for a detailed description of the sediment-dating methods previously used for Lake Orta, see Piscia et al., 2012). Analyses involving radioisotopes for sediment core dating may have to be done for only one core, the reference core, as differently shaded sediment layers can be visually matched to the corresponding layers of the reference core. The other halves of the cores can be used for collecting resting eggs of the species of interest. To this end, dated cores are cut into 1- to 2-cm slices along the vertical (i.e., time) axis, the slices transferred to small plastic bags, and the bags stored at $4{ }^{\circ} \mathrm{C}$ in darkness until further processing. All sediment cores should be photographed and the layers correlated to the reference core of Piscia et al. (2012) for dating. 
In order to extract resting eggs from the sediment samples, the most widely applied method of sugar-flotation developed by Onbé (1978) can be selected; for an alternative method based on colloidal silica, see Briski et al., (2013). First, a 1:1 solution (weight:volume) of sugar and water (in our laboratory we use artificial freshwater, see below) is prepared. One litre of water plus $1 \mathrm{~kg}$ of sugar result in about $1.7 \mathrm{~L}$ of sugar solution; this is enough liquid to dissolve roughly $20 \mathrm{~g}$ of fresh sediment. Next, the dissolved sediment is centrifuged at $3000 \mathrm{rpm}$ for $5 \mathrm{~min}$. Centrifuging concentrates the mud at the bottom of the tube, while resting eggs and subfossil remains are suspended in the supernatant. To collect the eggs, the supernatant is sieved through a net with a mesh width of $30 \mu \mathrm{m}$ in order to retain Brachionus resting eggs; the retained material is washed into a Petri dish. Using a stereomicroscope the resting eggs are separated from the other material and transferred to smaller (1-3 mL) dishes for hatching trials. Finally, the leftover mud in the centrifuge tube is screened again by re-suspending it in sugar solution and repeating the whole procedure until no further resting eggs are found (typically after 2-3 runs).

For hatching trials, viable looking resting eggs (García-Roger et al., 2005) are isolated. They can be transferred to multi-well plates (García-Roger et al., 2005; Piscia et al., 2012), Petri dishes (Walczyńska and Serra, 2014), or similar plates. Optimal hatching conditions (temperature, illuminance, and photoperiod) likely differ between species. Temperatures used to induce hatching of brachionid resting eggs are typically in the range of 17$25^{\circ} \mathrm{C}$ (García-Roger et al., 2005; Piscia et al., 2012; Walczyńska and Serra, 2014) with either a daily 16-h photoperiod ( 2000 lux, Piscia et al., 2012) or constant illumination (5000-10,000 lux; García-Roger et al., 2005; Walczyńska and Serra, 2014). In our laboratory, hatching trials under light (5000-6000 lux)/dark cycles of $16 \mathrm{~h} / 8 \mathrm{~h}$ at room temperature $\left(22-23^{\circ} \mathrm{C}\right)$ worked well for $B$. calyciflorus. One should check for neonates at least once per day for about two weeks. Viable resting eggs would usually hatch within one week of incubation (García-Roger et al., 2005; García-Roger et al., 2006; Walczyńska and Serra, 2014). During extended hatching trials one can transfer the eggs to new medium every 2-3 days in order to suppress fungal infections (García-Roger et al., 2005).

Once hatched, individual hatchlings can be transferred to small (35 $\mathrm{mm}$ in diameter) Petri dishes containing artificial freshwater (for logistic reasons, it is impossible to keep the rotifers in real Lake Orta water if the laboratory is not close to the lake). Soft synthetic freshwater (hereafter $\mathrm{EPA}_{\mathrm{s}}$ ) works well for culturing Lake Orta rotifers. EPA consists of $48 \mathrm{mg} \mathrm{NaHCO}, 30 \mathrm{mg} \mathrm{CaSO} \cdot 2 \mathrm{H}_{2} \mathrm{O}, 30 \mathrm{mg}$ $\mathrm{MgSO}_{4}$ (in case of Lake Orta rotifers we prefer to use 61.43 $\mathrm{mg} \mathrm{MgSO}_{4} \cdot 7 \mathrm{H}_{2} \mathrm{O}$ ), and $2 \mathrm{mg} \mathrm{KCl}$ dissolved in one litre of deionised water (Table 7 in U.S. Environmental Protection
Agency, 2002). To boost initial population growth, rotifers should be kept at a high food density of roughly five million Chlorella vulgaris (green alga) cells per millilitre. Hatchlings are then kept under natural light conditions at room temperature until they start reproducing. When population sizes reach 10-15 individuals the rotifers can be transferred to $15-\mathrm{mL}$ plastic tubes and stored at $20^{\circ} \mathrm{C}$ in complete darkness. After three days, the cultures can be transferred to 50$\mathrm{mL}$ plastic tubes while reducing the food density to about two million algal cells per millilitre. New food should be supplied every 2-3 days $\left(\sim 10^{6}\right.$ algal cells $\left.\mathrm{mL}^{-1} \mathrm{~d}^{-1}\right)$ and the rotifer cultures refreshed once per week by discarding about half of the culture volume and refilling the tubes with fresh $\mathrm{EPA}_{\mathrm{s}}$ and algae. Once the populations start reproducing sexually, resting eggs can be collected to preserve the lineages for future experiments. To this end, the resting eggs are stored in small plastic boxes (e.g., $22 \mathrm{~mm}$ x $13 \mathrm{~mm}$, diameter $\mathrm{x}$ height) filled with $\sim 1.5 \mathrm{~mL}$ of $\mathrm{EPA}_{\mathrm{s}}$. Keeping these boxes at $4^{\circ} \mathrm{C}$ in complete darkness will suppress further hatching.

Ideally, rotifers and algae would be cultured in the same medium. However, we found that Brachionus species from Lake Orta do not grow well in nutrient-rich medium. On the other hand, $C$. vulgaris does not grow in $\mathrm{EPA}_{\mathrm{s}}$. Therefore algae can be cultured in a modified version of WC medium (hereafter MWC) as described by Guillard and Lorenzen (1972; Table 2). Modifications of WC to produce MWC include the omission of $\mathrm{Na}_{2} \mathrm{SiO}_{3} \cdot 9 \mathrm{H}_{2} \mathrm{O}$ and the use of TES buffer $\left(0.115 \mathrm{~g} \mathrm{~L}^{-1}\right)$. The Chlorella cultures should be kept aerated and illuminated (16 h/8 h-light/dark cycles) and stored at about room temperature. Prior to feeding rotifers, the algae should be centrifuged (3000 rpm for five minutes) to remove the supernatant (MWC), and the algae should be resuspended in $\mathrm{EPA}_{\mathrm{s}}$ to reach the required food density. Fed this way, resurrected rotifer lineages from Lake Orta (the descendants of a single hatchling) can be cultured for several months.

Thanks to Lake Orta's well-documented history of industrial pollution (Bonacina and Baudo, 2001), resurrection ecology on rotifers from this lake offers a unique opportunity to investigate life-history processes under realistic environmental scenarios. In this context, we plan to start a research programme including a series of experiments that encompass three levels of organisation: species, population, and the individual. The rationale of the experimental approach is the same at all three levels. First, we plan to resurrect rotifers from different sediment layers with each layer representing a distinct, known period in Lake Orta's pollution history - and then to subject the resurrected rotifers to a set of environmental conditions representative of specific historic pollution levels such as pre-pollution, peak-pollution, lake-recovery, and post-recovery periods. We plan to monitor experimental popula- 
tions for up to two months and measure a variety of demographic (e.g., population density, stage structure) and life-history variables (survival, reproduction, etc.). At the species level, we can compare the only two brachionid species (or species complexes, see Fontaneto, 2014) found in Lake Orta sediments, B. calyciflorus and B. urceolaris. Such a comparison is straightforward, as resting eggs of the two species can occasionally be found in the same or similar (with respect to age) sediment layers. In particular, we plan to compare the species' tolerance to lake acidification as well as to varying levels of copper pollution, given that preliminary trials indicated that such experiments can be performed (Fig. 1). Since B. calyciflorus (4 anterior spines) and $B$. urceolaris ( 6 anterior spines) can easily be distinguished under the microscope, the two species of brachionids are also accessible to direct competition experiments. At the population level (i.e., within species), we plan to compare demographic and phenotypic responses of rotifers across layers. Specifically, we ask whether rotifer lineages historically exposed to increased levels of pollution (copper and acidification) did adapt to the toxic environments and, if so, whether these adapta-

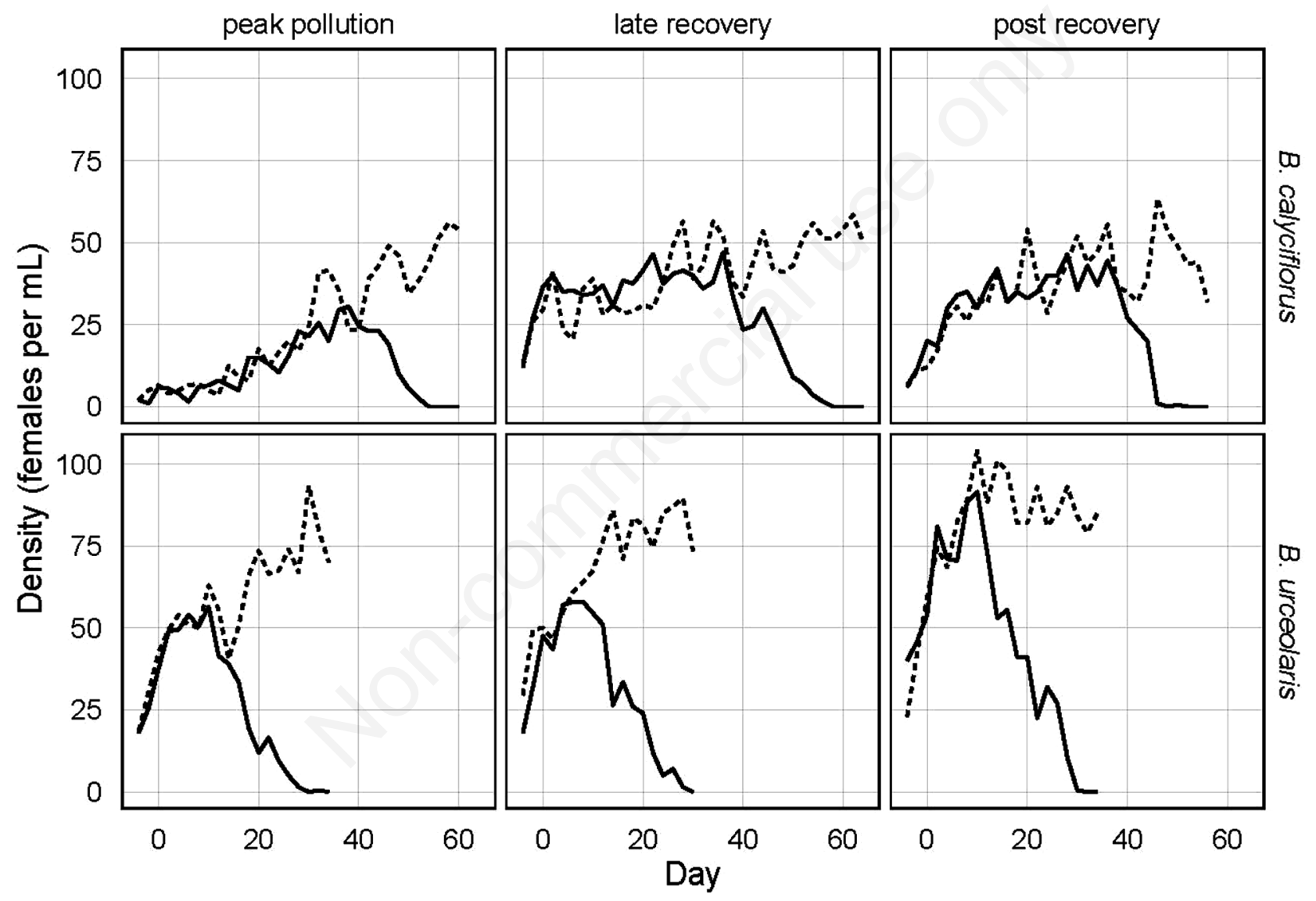

Fig. 1. Preliminary results of population dynamics of experimental rotifer cultures. Brachionus calyciflorus (top row) and B. urceolaris (bottom row) resurrected form sediments of Lake Orta were cultured in 50-mL plastic tubes in either unpolluted (dotted lines, constant environment) or increasingly copper-polluted (solid lines, deteriorating environment) artificial freshwater (EPA $)$ supplemented with green algae (C. vulgaris, $2 \times 10^{6}$ cells $\mathrm{mL}^{-1}$ ). EPA $\mathrm{s}$ and algae were renewed every second day. Rotifer densities were estimated from 2 -mL samples harvested at 48-h intervals prior to medium renewal. The copper treatment (addition of copper sulphate pentahydrate) started on day 0 (post-sampling) at a concentration of $2 \mu \mathrm{g} \mathrm{Cu}^{2+} \mathrm{L}^{-1}$ and was increased by $2 \mu \mathrm{g} \mathrm{Cu}^{2+} \mathrm{L}^{-1}$ every other day during medium renewal (i.e., even, positive numbers on the $\mathrm{x}$-axis also correspond to pollution concentrations in units of $\left.\mu \mathrm{g} \mathrm{Cu}^{2+} \mathrm{L}^{-1}\right)$. Left, middle, and right panels show examples of rotifer lineages resurrected from sediment layers corresponding to peak-copper pollution $\left(\sim 1960-1965 ; 70-100 \mu \mathrm{g} \mathrm{Cu}^{2+} \mathrm{L}^{-1}\right)$, late lake-recovery ( 1995-2000; 3-12 $\left.\mu \mathrm{g} \mathrm{Cu}^{2+} \mathrm{L}^{-1}\right)$, and post-recovery ( 2005-2012; copper virtually absent from the water column) periods, respectively. Sediment layers were dated by visual matching to a radioisotope-dated reference core (ORTA 07/2A; cf. Piscia et al., 2012). All rotifer cultures were kept at $20^{\circ} \mathrm{C}$ in the dark. Sampling of unpolluted cultures was terminated when the corresponding polluted culture had gone extinct, determined by whole-population screening during medium renewal (note that density estimates based on 2-mL subsamples usually dropped to zero in deteriorating environments a few days before the whole population went extinct). 
tions came at a cost (for an example of increased copper tolerance in resurrected Lake Orta Daphnia, see Piscia et al., 2015). At the individual level, we plan to measure stage- and size-dependent vital rates (i.e., survival, growth, development, reproduction) in order to gain a mechanistic understanding of the life-history processes and to investigate potential differences in these processes both within and between species. Finally, it would be ideal to couple the above comparison of the demographic and phenotypic responses of rotifers with competition experiments. In these experiments, rotifers resurrected from different layers would compete in a common garden, and the results of the competition would be evaluated using genetic analysis of the remnant individuals. The NIOO-KNAW has characterized 12 microsatellites markers to differentiate rotifer strains (Declerck et al., 2015), and there is potential for the genetic identification of $B$. calyciflorus strains from different pollution periods of Lake Orta. If this proves to be feasible, the fitness differences between the strains coming from different layers can be evaluated under direct competition in varying pollution levels. By using a bio-demographic perspective and an experimental approach, such analysis of resurrected rotifers would link adaptation, trait dynamics, and demography to shed light on the lifehistory responses to historical environmental changes.

\section{ACKNOWLEDGEMENTS}

We wish to thank Marina M. Manca and Michela Rogora for inviting us to write this review and opinion paper, and two anonymous reviewers for their comments improving the manuscript. We thank all the people involved in sampling sediment cores from Lake Orta, especially Andrea Lami, Piero Guilizzoni and Stefano Gerli. SN and SSSS thank PASPA, UNAM.

\section{REFERENCES}

Amaral-Zettler LA, 2012. Eukaryotic diversity at pH extremes. Front. Microbiol. 3:441.

Arnold WR, Diamond RL, Smith DS, 2010. The effects of salinity, $\mathrm{pH}$, and dissolved organic matter on acute copper toxicity to the rotifer, Brachionus plicatilis ("L" strain). Arch. Environ. Con. Tox. 59:225-234.

Baldi E, 1949. Il Lago d'Orta, suo declino biologico e condizioni attuali. Mem. Ist. ital. Idrobiol. 5:145-188.

Beers JR, Stewart GL, Hoskins KD, 1977. Dynamics of microzooplankton populations treated with copper: controlled ecosystem pollution experiment. Bull. Mar. Sci. 27:66-79.

Bērzinš B, Pejler B, 1987. Rotifer occurrence in relation to $\mathrm{pH}$. Hydrobiologia 147:107-116.

Bērzinš B, Pejler B, 1989a. Rotifer occurrence in relation to temperature. Hydrobiologia 175:223-231.

Bērzinš B, Pejler B, 1989b. Rotifer occurrence and trophic degree. Hydrobiologia 182:171-180.

Bērzinš B, Pejler B, 1989c. Rotifer occurrence in relation to oxygen content. Hydrobiologia 183:165-172.
Bielanska-Granier I, 2001. The psammic rotifer structure in three Lobelian Polish lakes differing in $\mathrm{pH}$. Hydrobiologia 446/447:149-153.

Boeckman CJ, Bidwell JR, 2006. The effects of temperature, suspended solids, and organic carbon on copper toxicity to two aquatic invertebrates. Water Air Soil Poll. 171:185-202.

Boggero A, Basset A, Austoni M, Barbone E, Bartolozzi L, Bertani I, Campanaro A, Cattaneo A, Cianferoni F, Corriero G, Dörr AM, Elia AC, Ficetola GF, Kamburska L, La Porta G, Lauceri S, Ludovisi A, Gaino E, Goretti E, Lorenzoni M, Manca M, Marchetto A, Morabito G, Nonnis Marzano F, Oggioni A, Pierri C, Riccardi N, Rossetti G, Ungaro N, Volta P, Zaupa S, Fontaneto D, 2014. Weak effects of habitat type on susceptibility to invasive freshwater species: an Italian case study. Aquat. Conserv. 24:841-852.

Bonacina C, 1970. [Il Lago d'Orta: ulteriore evoluzione della situazione chimica e della struttura della biocenosi lacustre].[Article in Italian]. Mem. Ist. Ital. Idrobiol. 26:141-204.

Bonacina C, 2001. Lake Orta: the undermining of an ecosystem. J. Limnol. 60:53-59.

Bonacina C, Baudo R, 2001. Lake Orta: a case study. J. Limnol. 60:166 pp.

Bonacina C, de Bernardi R, Taticchi MI, 1994. Types of response to environmental changes in cladoceran populations. Boll. Zool. 61:385-393.

Bonacina C, Pasteris A, 2001. Zooplankton of Lake Orta after liming: an eleven years study. J. Limnol. 60:101-109.

Borgmann U, Ralph KM, 1984. Copper complexation and toxicity to freshwater zooplankton. Arch. Environ. Con. Tox. 13:403-409.

Brett MT, 1989. Zooplankton communities and acidification processes (a review). Water Air Soil Poll. 44:387-414.

Briski E, Bailey SA, MacIsaac HJ, 2013. Separation strategies for invertebrate dormant stages contained in sediment. Aquat. Biol. 18:209-215.

Buikema AL Jr, Cairns J Jr, Sullivan GW, 1974. Rotifers as monitors of heavy metal pollution in water. Va. Polytech. Inst. St. Univ. Water Resour. Res. Cent. Bull. 71:1-74.

Calderoni A, Tartari GA, 2001. Evolution of the water chemistry of Lake Orta after liming. J. Limnol. 60:69-78.

Calderoni A, Mosello R, Quirci A, de Bernardi R, 1990. Recovery of Lake Orta by liming, p. 57-171. In: Proceedings VII Int. Lime Congr., Rome.

Cattaneo A, Asioli A, Comoli P, Manca M, 1998. Organisms' response in a chronically polluted lake supports hypothesized link between stress and size. Limnol. Oceanogr. 43: 1938-1943.

Cochrane BJ, Irby RB, Snell TW, 1991. Effects of copper and tributyltin on stress protein abundance in the rotifer $\mathrm{Bra}$ chionus plicatilis. Comp. Biochem. Phys. C 98:385-390.

De Meester L, Gómez A, Okamura B, Schwenk K, 2002. The Monopolization Hypothesis and the dispersal-gene flow paradox in aquatic organisms. Acta Oecol. 23:121-135.

Decaestecker E, Gaba S, Raeymaekers JA, Stoks R, Van Kerckhoven L, Ebert D, De Meester L, 2007. Host-parasite 'Red Queen' dynamics archived in pond sediment. Nature 450: 870-873.

Declerck SAJ, Malo AR, Diehl S, Waasdorp D, Lemmen KD, Proios K, Papakostas S, 2015. Rapid adaptation of herbivore consumers to nutrient limitation: eco-evolutionary feed- 
backs to population demography and resource control. Ecol. Lett. 18:553-562.

Deneke R, 2000. Review of rotifers and crustaceans in highly acidic environments of $\mathrm{pH}$ values $\leq 3$. Hydrobiologia 433: 167-172.

Enesco HE, Wolanskyj A, Sawada M, 1989. Effect of copper on lifespan and lipid peroxidation in rotifers. Age 12:19-23.

Fontaneto D, 2014. Molecular phylogenies as a tool to understand diversity in rotifers. Int. Rev. Hydrobiol. 99:178-187.

Franklin NM, Stauber JL, Markich SJ, Lim RP, 2000. pH-dependent toxicity of copper and uranium to a tropical freshwater alga (Chlorella sp.). Aquat. Toxicol. 48:275-289.

Gama-Flores JL, Sarma SSS, Nandini S, 2005. Interaction among copper toxicity, temperature and salinity on the population dynamics of Brachionus rotundiformis (Rotifera). Hydrobiologia 546:559-568.

García-Roger EM, Carmona MJ, Serra M, 2005. Deterioration patterns in diapausing egg banks of Brachionus (Müller, 1786) rotifer species. J. Exp. Mar. Biol. Ecol. 314:149-161.

García-Roger EM, Carmona MJ, Serra M, 2006. Hatching and viability of rotifer diapausing eggs collected from pond sediments. Freshwat. Biol. 51:1351-1358.

Gray DK, Arnott SE, 2009. Recovery of acid damaged zooplankton communities: measurement, extent, and limiting factors. Environ. Rev. 17:81-99.

Guerreiro CB, Foltescu V, de Leeuw F, 2014. Air quality status and trends in Europe. Atmos. Environ. 98:376-384.

Guillard RRL, Lorenzen CJ, 1972. Yellow-green algae with chlorophyllide c. J. Phycol. 8:10-14.

Gulati RD, Van Donk E, 2002. Lakes in the Netherlands, their origin, eutrophication and restoration: state-of-the-art review. Hydrobiologia 478:73-106.

Hyne RV, Pablo F, Julli M, Markich SJ, 2005. Influence of water chemistry on the acute toxicity of copper and zinc to the cladoceran Ceriodaphnia cf dubia. Environ. Toxicol. Chem. 24:1667-1675.

Janssen CR, Ferrando MD, Persoone G, 1994. Ecotoxicological studies with the freshwater rotifer Brachionus calyciflorus: IV. Rotifer behavior as a sensitive and rapid sublethal test criterion. Ecotox. Environ. Safe. 28:244-255.

Kallqvist T, Meadows BS, 1978. Toxic effect of copper on algae and rotifers from a soda lake (Lake Nakuru, East Africa). Water Res. 12:771-775.

Kaya M, Fontaneto D, Segers H, Altindag A, 2010. Temperature and salinity as interacting drivers of species richness of planktonic rotifers in Turkish continental waters. J. Limnol. 69:297-304.

Kerfoot WC, Robbins JA, Weider LJ, 1999. A new approach to historical reconstruction: combining descriptive and experimental paleolimnology. Limnol. Oceanogr. 44:1232-1247.

Lampert W, Sommer U, 1997. Limnoecology: the ecology of lakes and streams. Oxford University Press, London: $336 \mathrm{pp}$.

Luna-Andrade A, Aguilar-Duran R, Nandini S, Sarma SSS, 2002. Combined effects of copper and microalgal (Tetraselmis suecica) concentrations on the population growth of Brachionus plicatilis Müller (Rotifera). Water Air Soil Poll. 141:143-153.

Manca M, Comoli P, 1995. Temporal variations of fossils Cladocera in the sediments of Lake Orta (N. Italy) over the last 400 years. J. Paleolimnol. 14:113-122.
Markich SJ, Camilleri C, 1997. Investigation of metal toxicity to tropical biota: Recommendations for revision of the Australian water quality guidelines. Supervising Scientist Report 127, Supervising Scientist, Canberra.

McIntosh AW, Kevern NR, 1974. Toxicity of copper to zooplankton. J. Environ. Qual. 3:166-170.

Monti R, 1930. [La graduale estinzione della vita nel limnobio del Lago d'Orta].[Article in Italian]. Rend. Ist. Lomb. Sc. Lett. 63:3-22.

Moser M, Weisse T, 2011. The most acidified Austrian lake in comparison to a neutralized mining lake. Limnologica 41:303-315.

Muirhead JR, Ejsmont-Karabin J, MacIsaac HJ, 2006. Quantifying rotifer species richness in temperate lakes. Freshwat. Biol. 51:1696-1709.

Obertegger U, Manca M, 2011. Response of rotifer functional groups to changing trophic state and crustacean community. J. Limnol. 70:231-238.

Obertegger U, Fontaneto D, Flaim G, 2012. Using DNA taxonomy to investigate the ecological determinants of plankton diversity: occurrence of Synchaeta (Rotifera, Monogononta) in mountain lakes. Freshwater Biol. 57:1545-1553.

Onbé T, 1978. Sugar flotation method for sorting the resting eggs of marine cladocerans and copepods from sea-bottom sediment. Bull. Jap. Soc. Sci. Fish. 44:1411.

Orsini L, Schwenk K, De Meester L, Colbourne JK, Pfrender ME, Weider LJ, 2013. The evolutionary time machine: using dormant propagules to forecast how populations can adapt to changing environments. Trends Ecol. Evol. 28: 274-282.

Papakostas S, Michaloudi E, Proios K, Brehm M, Verhage L, Rota J, Pena C, Stamou G, Pritchard VL, Fontaneto D, Declerck SAJ, 2016. Integrative taxonomy recognizes evolutionary units despite widespread mitonuclear discordance: evidence from a rotifer cryptic species complex. Syst. Biol. in press.

Pejler B, 1974. On the rotifer plankton of some East African lakes. Hydrobiologia 44:389-396.

Piscia R, Colombini M, Ponti B, Bettinetti R, Monticelli D, Rossi V, Manca M, 2015. Lifetime response of contemporary versus resurrected Daphnia galeata Sars (Crustacea, Cladocera) to $\mathrm{Cu}(\mathrm{II})$ chronic exposure. Bull. Environ. Contam. Toxicol. 94:46-51.

Piscia R, Guilizzoni P, Fontaneto D, Vignati DAL, Appleby PG, Manca M, 2012. Dynamics of rotifer and cladoceran resting stages during copper pollution and recovery in a subalpine lake. Ann. Limnol. - Int. J. Limnol. 48:151-160.

Ponti B, Piscia R, Bettinetti R, Manca M, 2010. Long-term adaptation of Daphnia to toxic environment in Lake Orta: the effects of short-term exposure to copper and acidification. J. Limnol. 69:217-224.

Roesijadi G, 1992. Metallothioneins in metal regulation and toxicity in aquatic animals. Aquat. Toxicol. 22:81-113.

Rogora M, Kamburska L, Mosello R, Tartari G, 2016. Lake Orta chemical status 25 years after liming: problems solved and emerging critical issues. J. Limnol. 75(s2):93-106.

Root TL, Price JT, Hall KR, Schneider SH, Rosenzweig C, Pounds JA, 2003. Fingerprints of global warming on wild animals and plants. Nature 421:57-60.

Sarma SSS, Brena-Bustamante P, Nandini S, 2008. Body size 
and population growth of Brachionus patulus (Rotifera) in relation to heavy metal (copper and mercury) concentrations. J. Environ. Sci. Heal. A 43:547-553.

Sarma SSS, Corral-Jácquez FI, Nandini S, Brena-Bustamante P, 2010. Population level indicators of stress: Effects of two heavy metals (copper and mercury) on the growth of Lecane quadridentata (Ehrenberg, 1830) (Rotifera: Lecanidae). J. Environ. Sci. Heal. A 45:32-36.

Snell TW, Janssen CR, 1995. Rotifers in ecotoxicology: a review. Hydrobiologia 313:231-247.

Snell TW, Joaquim-Justo C, 2007. Workshop on rotifers in ecotoxicology. Hydrobiologia 593:227-232.

Taranu ZE, Gregory-Eaves I, Leavitt PR, Bunting L, Buchaca T, Catalan J, Domaizon I, Guilizzoni P, Lami A, McGowan S, Moorhouse H, Morabito G, Pick FR, Stevenson MA, Thompson PL, Vinebrooke RD, 2015. Acceleration of cyanobacterial dominance in north temperate-subarctic lakes during the Anthropocene. Ecol. Lett. 18:375-384.

U.S. Environmental Protection Agency, 2002. Methods for measuring the acute toxicity of effluents and receiving waters to freshwater and marine organisms, $5^{\text {th }}$ ed. Office of Water, Washington DC: 266 pp.

Vollenweider RA, 1963. Studi sulla situazione attuale del regime chimico e biologico del Lago d'Orta. Mem. Ist. Ital. Idrobiol. 16:21-125.

Wærvågen SB, Nilssen JP, 2003. Major changes in pelagic rotifers during natural and forced recovery from acidification. Hydrobiologia 499:63-82.

Walczyńska A, Serra M, 2014. Species size affects hatching response to different temperature regimes in a rotifer cryptic species complex. Evol. Ecol. 28:131-140.

Weisse T, Laufenstein N, Weithoff G, 2013. Multiple environmental stressors confine the ecological niche of the rotifer Cephalodella acidophila. Freshwater Biol. 58:1008-1015.

Weithoff G, 2005. On the ecology of the rotifer Cephalodella hoodi from an extremely acidic lake. Freshwat. Biol. 50:1464-1473. 